\title{
Style Matters
}

\section{Guidelines on authorship}

\section{INTERNATIONAL COMMITTEE OF MEDICAL JOURNAL EDITORS}

At its last meeting the International Committee of Medical Editors (the Vancouver group) drew up the following guidelines on authorship and on other contributions that should be acknowledged. The committee also expanded the section on information to be given in the covering letter to include details of any conflict of interest and clarify the position of the author responsible for final approval of proofs. These guidelines will be incorporated into the Uniform Requirements for the Submission of Manuscripts to Biomedical Journals ${ }^{1}$ when it is next revised.

\section{Guidelines on authorship}

Each author should have participated sufficiently in the work to take public responsibility for the content. This participation must include: (a) conception or design, or analysis and interpretation of data, or both; $(b)$ drafting the article or revising it for critically important intellectual content; and (c) final approval of the version to be published. Participation solely in the collection of data does not justify authorship.

All elements of an article ( $a, b$, and $c$ above) critical to its main conclusions must be attributable to at least one author.

A paper with corporate (collective) authorship must specify the key persons responsible for the article; others contributing to the work should be recognised separately (see Acknowledgments and other information).

Editors may require authors to justify the assignment of authorship.

\section{Acknowledgments of contributions that fall short of authorship}

At an appropriate place in the article (title page, footnote, or appendix to the text; see journal's requirements) one or more statements should specify: $(a)$ contributions that need acknowledging but do not justify authorship, $(b)$ acknowledgments of technical help, (c) acknowledgments of financial and material support, and $(d)$ financial relationships that may constitute a conflict of interest.

Persons who have contributed intellectually to the paper but whose contribution does not justify authorship may be named and their contribution described-for example, "advice," "critical review of study proposal," "data collection," "participation in clinical trial." Such persons must have given their permission to be named.

Technical help should be acknowledged in a separate paragraph from the contributions above.

Members of the committee are: Dr A Blum, New York State fournal of Medicine, New York; Dr A Brass, Medical fournal of Australia, Sydney; Dr O Harlem, Norwegian Medical fournal, Oslo; Dr E Huth (co-secretary), Annals of Internal Medicine, Philadelphia; Dr S P Lock (co-secretary), British Medical Fournal, London; Dr G Lundberg, Fournal of the American Medical Association, Chicago; Dr P Morgan, Canadian Medical Association fournal, Ottawa; Dr I Munro, The Lancet, London; Dr A Relman, New England Medical fournal, Boston; Dr P Riis, Danish Medical fournal, Copenhagen; Dr R Robinson, New Zealand Medical foumal, Dunedin; Dr I Vartiovaara, Finnish Medical fournal, Helsinki.
Financial or material support from any source must be specified. If a paper is accepted it may also be appropriate to include mention of other financial relationships that raise a conflict of interest, but initially these should be outlined in the covering letter.

\section{Information to be included in the covering letter}

Manuscripts must be accompanied by a covering letter. This must include: $(a)$ information on prior or duplicate publication or submission elsewhere of any part of the work; $(b)$ a statement of financial or other relationships that might lead to a conflict of interests; $(c)$ a statement that the manuscript has been read and approved by all authors; and $(d)$ the name, address, and telephone number of the corresponding author, who is responsible for communicating with the other authors about revisions and final approval of the proofs.

The manuscript must be accompanied by copies of any permissions to reproduce published material, to use illustrations of identifiable persons, or to name persons for their contributions.

1 International Committee of Medical Journal Editors. Uniform requirements for manuscripts submitted to biomedical journals. BrMed $\mathcal{F}$ 1982;284:1766-70.

A 42 year old woman had a hysterectomy four years ago with conservation of the ovaries. She now complains of episodes of abdominal swelling and oedema lasting about four days and occurring every ten days. She takes hydrochlorothiazide amiloride (Moduretic) during these episodes. What is the cause and what treatment is recommended?

Cyclic ovarian activity continues when the ovaries are conserved after hysterectomy. ${ }^{1}$ It has been known for many years that oedema of the abdomen, hands, and feet can occur in the latter part of the normal menstrual cycle ${ }^{2}$ and usually disappears at menstruation. In one study $48 \%$ of normal subjects gained $1 \mathrm{~kg}$ or more during the premenstrual period. ${ }^{2}$ During the luteal phase of the cycle there is an increase in mean 24 hour urine flow and excretion of sodium, ${ }^{3}$ and an increase in renin, angiotensin II, and aldosterone. ${ }^{4}$ In a double blind study an aldosterone antagonist, spironolactone, reduced weight and relieved psychological symptoms in $80 \%$ of symptomatic women. ${ }^{4}$ Thiazide diuretics have also been said to be effective in the premenstrual syndrome, but they have not been so impressive in double blind trials. ${ }^{5}$ Numerous drugs have been tried in the premenstrual syndrome, but some of them, such as the oral contraceptive pill, would probably be inappropriate in this patient because of her age. According to a recent review, the most effective treatment for this particular symptom is spironolactone $100 \mathrm{mg}$ daily, beginning three days before the expected onset of symptoms. ${ }^{5}$ - JAMES OWEN DRIFE, senior lecturer in obstetrics and gynaecology, Leicester.

Backstrom CT, Boyle H, Baird T. Persistence of symptoms of premenstrual tension in hysterectomized women. Br $\mathcal{7}$ Obstet Gynaecol 1981;88:530-6.

2 Thorn GW, Nelson KR, Thorn D. A study of the mechanism of edema associated with menstruation. Endocinology 1938;22:155-63.

3 Parboosingh J, Doig A, Michie EA. Renal excretion of water and solutes during the normal menstrual cycle. Fournal of Obstetrics and Gynaecology of the British Commonwealth 1973;80: 978-83.

4 O'Brien PMS, Craven D, Selby C, Symonds EM. Treatment of premenstrual syndrome by spironolactone. Br 7 Obstet Gynaecol 1979;86:142-7.

5 O'Brien PMS. The premenstrual syndrome: a review of the present status of therapy. Drugs 1982;24:140-51. 